\title{
THE REPUBLIC OF MACEDONIA AND BALKANS DURING THE REFUGEE CRISIS
}

\author{
Nikola Kiskoski, M.Sc, \\ E-mail: nkiskoski@gmail.com
}

\begin{abstract}
At a time of mutual tolerance and shortening the procedures for free movement of people and maximum respect of the human rights, we face the challenge of the refugee crisis, where contrary to the above, we must build a fence in order to protect the country's territory and prevent the human rights violations. The national security is the basis for the successful development and survival of a state, as well as a guarantee for the realization of personal and collective security. A series of measures and procedures must be appropriately planned and implemented in order to protect the state from the challenges and threats of modern times such as asymmetric threats, terrorism, especially dealing with the refugee crisis. The measures and procedures which will be implemented must be consistent with the existing laws and respect the human rights, and they should be implemented by relevant state institutions. The decision to use and provide special measures and procedures for protecting and dealing with the refugee crisis must be made by state officials and comply with regional security. It is very important for the crisis management to be lead by professionals within its appropriate institutions and the cooperation must be on a regional level. We need to analyze the refugee crisis in the Balkans and to anticipate the direction in which this refugee crisis will develop in the future.
\end{abstract}

Keywords: refugee crisis, national security, collective security, crisis management.

\section{Introduction}

The refugee crises and migration as a phenomenon date back since ancient times. People migrated as a result of: torture by the conquerors, the horror that was brought by the wars, but rarely, the migration was a consequence of natural disasters (earthquakes, 
floods, fires, landslides and so on). The emergence of various infectious diseases and epidemics was a reason for migration as well. Naturally, since ancient times the refugees moved along river valleys, they always moved on the shortest, the cheapest and the safest route. In recent history, the difference in the development between Europe and Western countries on one side, and Africa and Asia on the other side has become a common cause for migration with the hope for a better life. The refugee crises and the fear of the unknown is one of the greatest horrors of every person. The refugee who decided to leave their home, to leave behind everything they own and risk their life and the lives of their families in a hopeless situation. On the other hand, the fear of the recipient countries that terrorist are infiltrated among the refugees should also be justified.

The purpose of this paper is to provide an analysis of the consequences and effects of the refugee crisis in Macedonia and the Balkans. It should be mentioned that all data included in the paper are derived only from publicly available sources.

What implications does the Republic of Macedonia have from the refugee crisis in the last two decades?

What are the consequences of the refugee crisis in the Balkans? Analysis and expectations about the situation ahead?

\section{Defining the terms: crisis, refugee, migrant}

According to Oxford Dictionary the word crisis is a turning point, and can be explained as the time when difficult and important decisions must be made or decisive point from which we can expect a positive or negative development. Also, crisis can be explained as a time of intense difficulty or danger. ${ }^{77}$

There are several ways of dividing the crisis. According to the classical typology, the crisis is divided into:

- a crisis caused by natural factors;

- a crisis caused by human factors, and

- a special crisis. ${ }^{78}$

Here emerges the need to define and explain the terms refugee and migrant. According to the basic definitions that exist in the literature, the term refugee can say the following: According to the organization UNHCR, a refugee is a person who is forced to leave their country because of persecution, war or violence. The fugitive is persecuted due to their race, religion, nationality, political opinion or membership in a particular social group. Most refugees cannot return home or are afraid to do so.

\footnotetext{
77 http://www.ox.ac.uk/

${ }^{78}$ Марина Митревска, Кризен менаџмент, Филозофски факултет, 2016
} 
The war, ethnic, tribal and religious violence is the leading cause for the creation of refugees. ${ }^{79}$

According to all definitions about refugees, the main reason is the violence against civilians. According to the UN for the term migrant can be defined as the following: A migrant is any person who temporarily or permanently lives in a country in which they were not born. In a broader sense and depending on the policy of the country, the person may obtain the status of a migrant even if they born in that country. ${ }^{80}$

Therefore, the migrant leaves their country consciously, very often their trip is previously planned and they can even choose the country where they want to travel. If the migrant fails in their plans, they may return to their country and home. Unlike them, the refugee is forced to migrate. Their situation is difficult and hopeless, and their return home is almost impossible. Of all the refugees in 2015 , only $1 \%$ of them have returned to their homes.

For the refugees and displaced persons, the only legal document is the Geneva Refugee Convention of 1951 and the Protocol of 1967. This Convention was adopted by 145 delegates from as many countries that have signed the basic document. ${ }^{81}$

\section{The refugee crisis in general and the routes to Europe}

Before we start with the analysis of the last refugee crisis that began as a result of the conflict in Syria, we should have a brief overview of the refugee crisis in the region, as well as the refugee routes used mainly for transit to Europe. The migration route of Africa, Middle East to Europe is a process that dates back to 15-20 years ago. The first migrant route that was used was the Western Mediterranean route stretching in the South - North direction, from Morocco, north towards Spain. The next, newer route is the Central - Mediterranean route also in the direction from South to North direction, from Libya and Egypt to Italy. The latest route is east - Mediterranean route that stretches in the direction East - North, from Turkey to Western Europe. After the closure of a part of this direction, the East - Mediterranean route gets a new direction, which is Turkey Balkan Peninsula - Central Europe. As a result of this change, the name of the route was changed into East - Mediterranean - Balkan route. According to the above mentioned, it can be said that in recent history there are three main routes in Europe - see picture No.1. These three routes are expected to be present in the future as well.

\footnotetext{
79 http://www.unrefugees.org/what-is-a-refugee/

$80 \mathrm{http}: / /$ www.unesco.org/new/en/social-and-human-sciences/themes/international-migration/ glossary/migrant/

81 http://www.unhcr.org/1951-refugee-convention.html
} 


\section{Security}

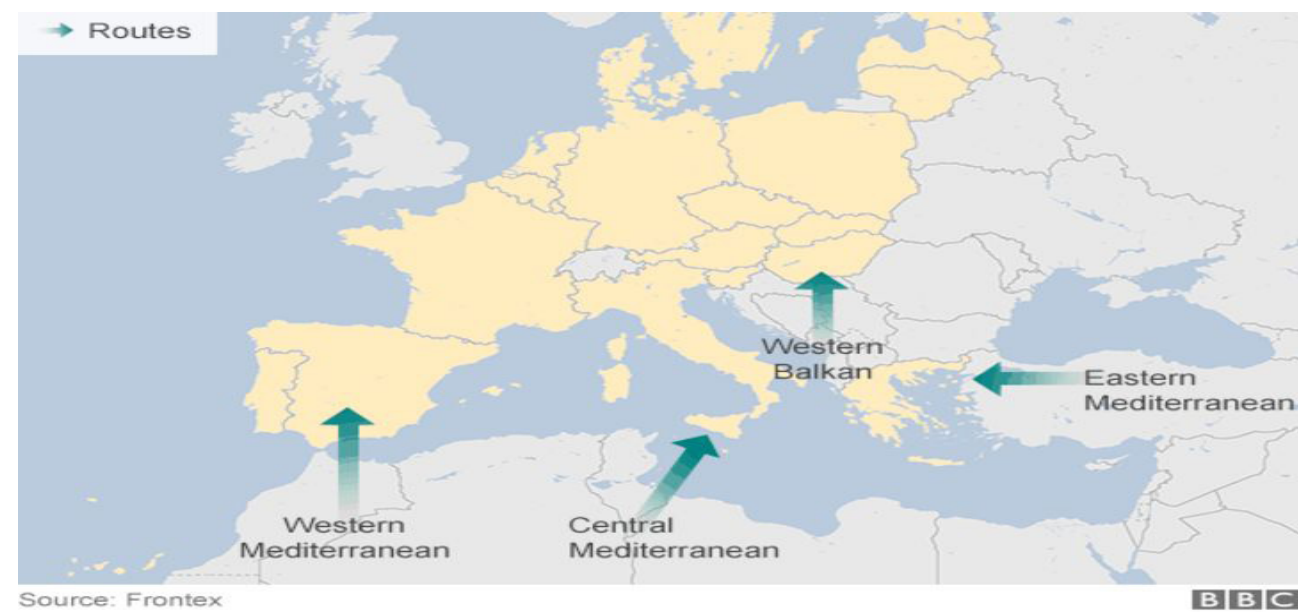

82

\section{Picture No.1}

The refugee crisis has become one of the biggest problems that the European Union and its Member States have to face. The European Union has for decades been committed to the absence of limits, maximum respect for the human rights and freedoms on the one hand and ensuring the safety of the citizens on the other. The abolition of internal borders and the lack of control of persons staying and transiting through the European Union have proved to be the biggest drawback in the fight against terrorism and the location of persons suspected of terrorist attacks. As an example, those who entered the EU via the Balkan route, through Hungary, can transit freely in all EU countries and carry out terrorist attacks in France. French security services may have no information on that person if that person during their stay in France is not registered at a certain address, hotel, if they do not rent a car and so on. I want to mention that the reduction or abolition of borders within the EU is a major problem for the realization of national security.

It should be noted that the migrant crisis has also become quite a lucrative business for smugglers and criminals. The smuggling of migrants is more present in our region as well. On average, a migrant pays ten to twenty thousand euros to travel from Syria to Europe and usually the ultimate goal of most migrants is Germany. It is considered that the business of smuggling migrants reaches 4 to 5 billion Euros annually. The problem with migration is one of the largest problems. It is a problem for the European Union as the final destination and purpose of all migrants, but it should be noted that migration is a major problem for the countries through which the migrants transit, and which are not members of the EU. These are the countries of the Balkan Peninsula.

$82 \mathrm{http} / / /$ www.bbc.com/news/world-europe 


\section{Sececurity}

\section{The refugee crisis in Macedonia and the Balkans}

The location of the Republic of Macedonia is very important strategically, but it is also one of the key countries for the transit of migrants to other countries in the Balkans and Europe. Historic Macedonia has almost always been a crossroad and a part of some major developments. Ever since the Roman Empire passed through Macedonia: VIA - Egnatia as communication direction from East to West and communication VIA -Militaris that stretched from South to North and is almost identical to today's so-called Balkan route..$^{83}$

If we make a brief analysis of the last two - three decades, we will come to the conclusion that the refugee crisis that is currently happening as a consequence of the war in Syria is the fifth in a row for this short period. We should mention that about 1,200 people were treated in the country in 1991 as a result of the contemporary developments in the Republic of Albania and then in 1992, between 30 and 40 thousand people arrived in Macedonia after they escaped from the war in Bosnia and Herzegovina. During the Kosovo crisis in 1999 , our country took care of more than 350,000 people. As a fourth crisis is the conflict in 2001, and as a consequence, nearly 90,000 people were registered as internally displaced persons. It should be noted that in general, in the Balkans in recent years there were several developments that led to several refugee crises and the wars in Slovenia, Croatia, and Bosnia and Herzegovina, the developments in Kosovo, NATO's military intervention against Serbia, and the conflict in the Republic Macedonia and so on. The refugee crisis has had an impact in the demographic composition of the countries receiving the refugees. The migrants in recent years have passed through our country and used the Vardar valley, and after leaving the Republic of Macedonia they continued along the Morava River through the neighboring Republic of Serbia to the border with Hungary joining the European Union. After the closure of the border with Hungary and the construction of the wire obstacle, the refugees continued west to Croatia, Slovenia and Austria. This so-called Balkan route is shown in picture No. 2 .

${ }^{83}$ http://morm.gov.mk/wp-content/uploads/2017/01/31_SMO-za-web.pdf 


\section{Secuurity}

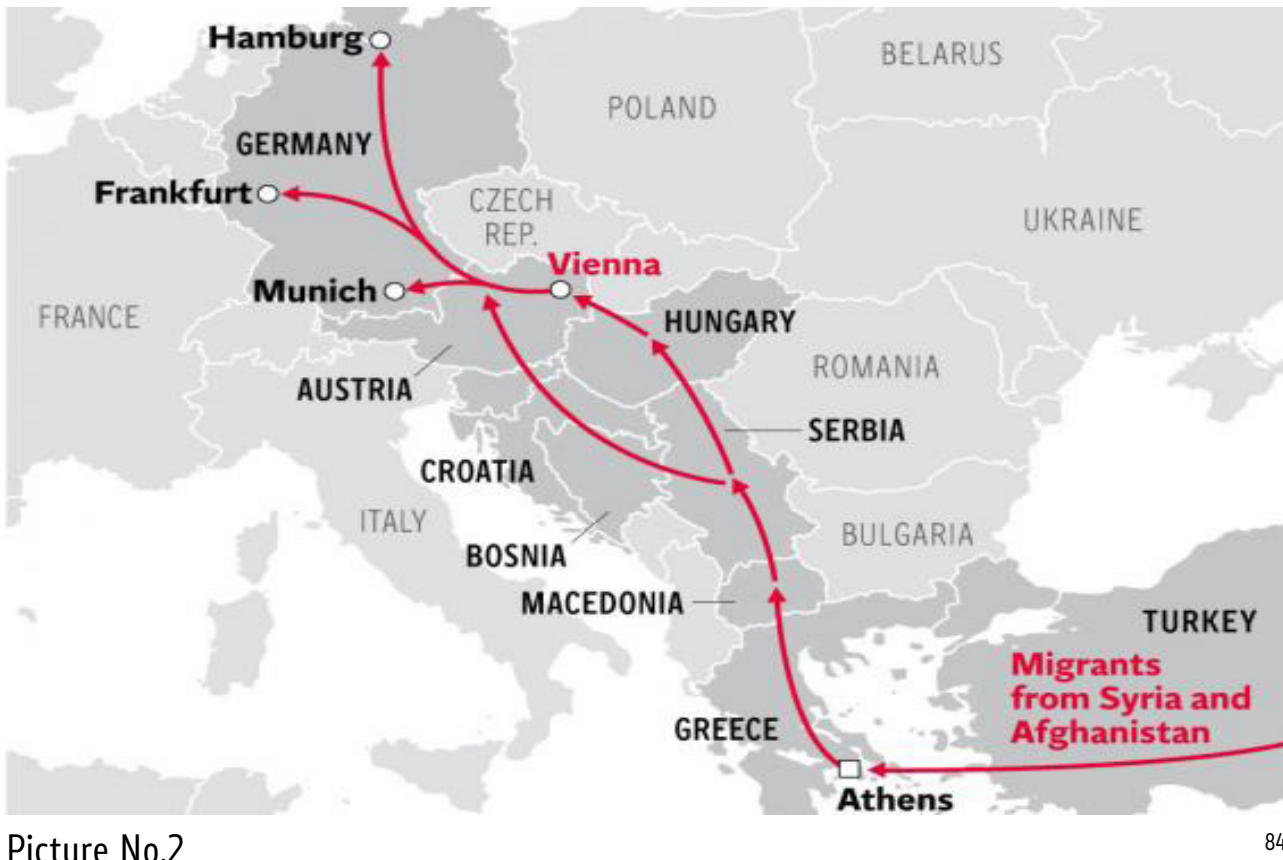

At the beginning of the refugee crisis in Macedonia the police managed to deal with the refugees until the middle of August 2015 when the border daily received more than ten thousand people. This was immediately followed by the decision to recruit the Army of Republic of Macedonia to assist in the dealing with the refugees. A system for registering persons was implemented as well. All persons transiting through Macedonia were registered by the army and police officials to assist the police forces of the European Union. Some irregularities were recorded. Some of those documents had the same identity, the same date of birth, many young adults, some of them with injuries characteristic of armed conflict. All these people came to the border of the Republic of Macedonia from a member state of the European Union - Greece. It can immediately be concluded that the control system and the selection of people receiving refugee status were tricked at the very entrance to the Greece Republic. Some of the documents were created on the territory of Greece. The migrants first enter a Member State of the European Union and the Schengen area, and then they come in Macedonia. In this context, the President of the Republic of Macedonia, Dr. Gjorge Ivanov on 11.03.2016, in an interview with the German newspaper "Bild" said that Macedonia is in an absurd situation because Macedonia is not a member of the European Union and NATO and must protect Europe from the European Union. ${ }^{85}$ The above can be seen at the next picture No. 3 .

${ }^{84}$ http://www.independent.co.uk/

${ }^{85}$ http://morm.gov.mk/wp-content/uploads/2017/01/31_SM0-za-web.pdf 


\section{Securility}

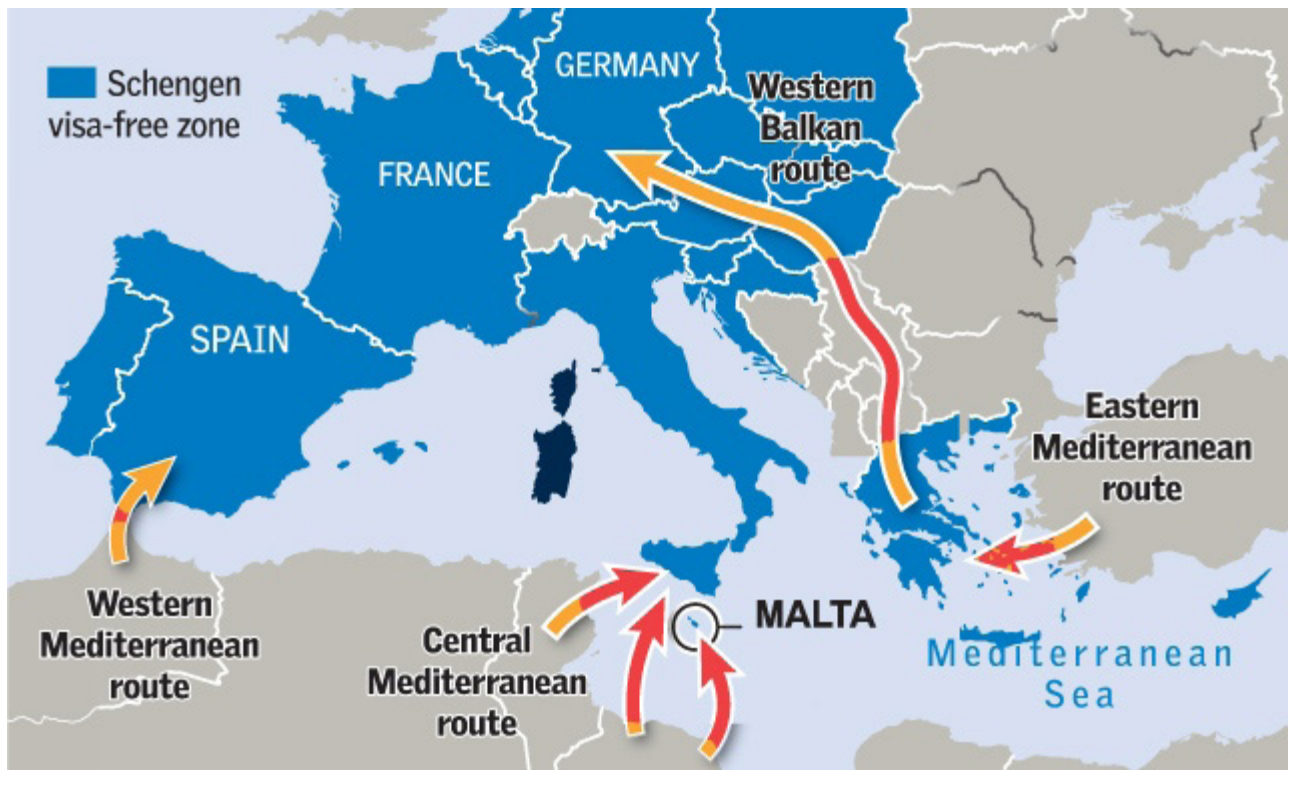

Picture No.3

In order to stabilize the situation and to avoid escalation, in November 2015 the Army began setting up a wire fence with length of more than $37 \mathrm{~km}$ close to the routes of illegal entry and transit through Macedonia. With the installation of the fence the situation was normalized. Macedonia has made legislative amendments to the Law on Asylum and Temporary Protection "Official Gazette number 101/2015 year." Before this change was made, the refugees only had a legal possibility, and that was to seek asylum in the country. Because their aim was not to request asylum in our country, the legal amendment provided them the right for residence in the country, the right to use public transport, the right to use humanitarian aid and so on. All refugees had to go through bandwidth stations and then to use the organized transport with Macedonian trains, buses and taxi companies to the northern border from where they continued their transit through the Republic of Serbia. These amendments established order in the dealing with the refugees. They also had proper medical care and adequate humanitarian assistance. Czech Republic donated 24 vehicles for the police and financial aid. On the other hand, the illegal trade and smuggling of refugees was reduced to a tolerable minimum, the possibility of corruption of all persons involved in dealing with the refugee crisis was also reduced. In 2015 according to the European Union 880,000 people arrived in Europe through the Balkan route, and at the beginning of 2016, the number was 130000 . So, at the beginning of March 2016 a decision was made to close the Balkan route through

${ }^{86} \mathrm{http}: / /$ eurasian-research.org 
Macedonia. About 10,000 people were trapped in Greece and relatively few in Serbia. This put an end to the refugee crisis in the region, at least temporarily. Since then, almost everyday some refugees cross the border but those are individual cases.

Similarly to Macedonia, the refugees have used Serbia only for transit. The problems and challenges were similar. Serbia have also partly engaged the security forces and border police and army. In neighboring Bulgaria, the blocking of the border and the engagement of the Army occurred much earlier than in our country. In cooperation with Greece, it raised wire fence on the border with Turkey. In order to arrive to Bulgaria, the refugees had to travel on quite large water surface and therefore, the impact of the refugee crisis in Bulgaria is much lower than in most other countries. This is confirmed by the figures for asylum seekers according to official sources, in 2012 there were 1,387 people, in 2013 there were 7,144 people, in 2014 there were 11,081 and in 2015, 20,391 people. ${ }^{87}$ Bulgaria arguments for dealing with the refugee crisis are based on the following values: Bulgaria is one of the poorest countries in the EU, a member of the Schengen zone, it has no budget for dealing with refugees, refugees are a problem for the national security and a different mentality and so on. Based on the arguments, the Republic of Bulgaria is given maximum protection of its borders and we can say that it is the first of all the countries that have taken security measures. Albania unlike the other Balkan countries had a relatively easier task in dealing with the refugee crisis. The number of illegal crossings of the border is far smaller, as well as the number of people who transited through Albania. After closing the Balkan route through Macedonia, the number of refugees crossing Albania was increased. These were people trapped in Greece and those transiting in that period in Greece. Immediately after that, the main refugee route was directed to Turkey.

It is safe to say that besides the Republic of Macedonia, the situation in Greece was rather complicated. Their situation has proved the inefficiency in the handling of such situations, not only of Greece but of the entire European Union. All of them were surprised and relatively unprepared for this challenge. The officials in Greece have got the impression that the main task and number one priority is to provide quickly organized transport to the border with Macedonia and to get rid of the refugees, there by not taking care for their identification and detection of potentially dangerous individuals. There are reports that some counterfeit documents were produced in Greece and then some people have used them to travel to the western countries. On the account of the refugees, Greece had some financial benefits from the transport of those people and by selling them some products. After the setting of the wire fence on the border on the Macedonia's side, the other side sold some tools to the refugees, like scissors for cutting metal wire in order to make passages through the fence. After closing the route the situation was normalized. The borders with the exception of certain countries were insufficiently secured.

${ }^{87}$ http://library.fes.de/pdf-files/bueros/sofia/12570.pdf 


\section{Security}

\section{Conclusion}

The refugee crisis that happened in the past few years and is likely to happen in the upcoming period leads to more conclusions and directions for the future and a number of recommendations.

- As mentioned, this refugee crisis has shown that the borders are quite insufficiently secured. The lack of will to resolve the refugee problem and the inertia of institutions. Transferring responsibility to other states by passing refugees almost with no records. This levity proved in practice. Some of the persons who carried out terrorist attacks in European countries transited through this refugee route. The terrorist who sowed death in Paris spent the whole Balkan route with Syrian passport under the name Ahmed Almuhamed without being identified and stopped (PictureNo. 4). He entered Greece on 03.10.2015 and on 07.10.2015 he entered Serbia and then through Croatia and Austria headed for Paris. In this terrorist attack 150 innocent people were killed. Who will bear the responsibility for this event? Is the mistake is in the record or in the work of officials in Greece? From this event it can be concluded that not every person is a refugee and serious work should be done there. Greece is part of the Schengen zone and the initial filter needs to be done there. On average, most of the refugees are men at the age between 18 and 35 and should be an alarm for the security services. A number of these people had injuries characteristic of armed conflict and so on.

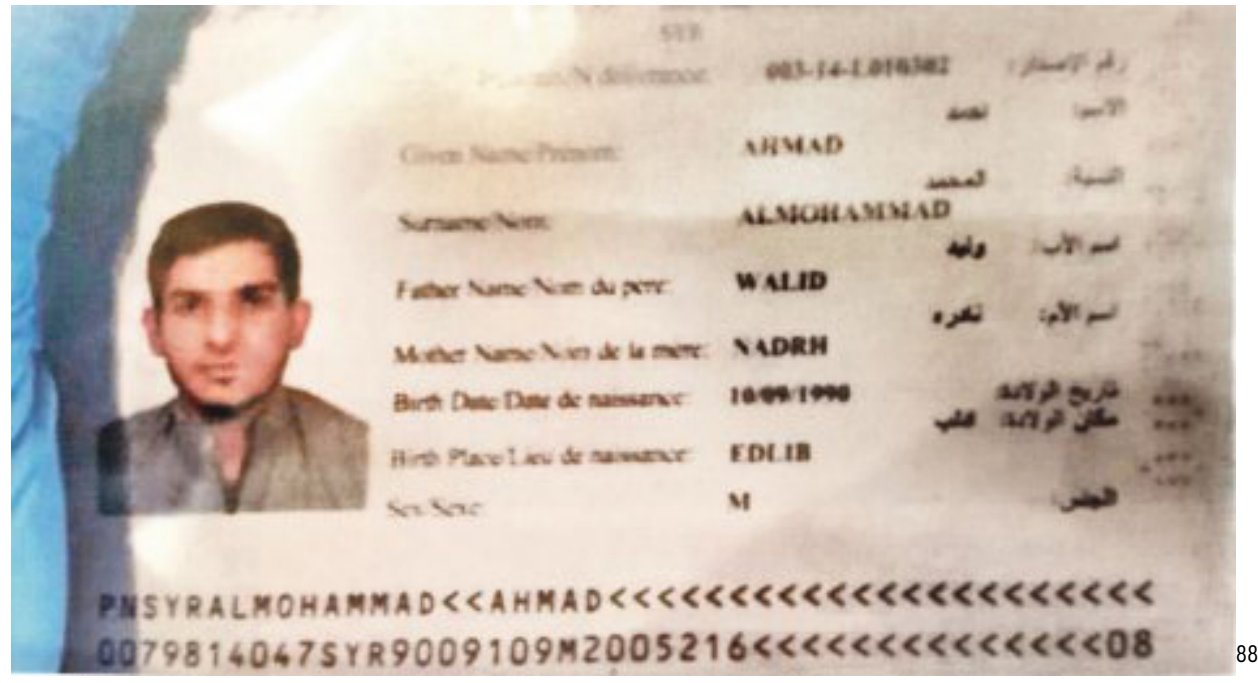

${ }^{88} \mathrm{http}: / /$ vecer.mk/makedonija/mvr-dosega-chetiri-lica-so-ime-ahmad-almohamadvlegle-vo-makedonija-od-grija 
- Another logical conclusion that follows is that there are stale and inadequate laws considering this issue. Here we can mention the example of the Republic of Macedonia. In order for the refugees to be transiting through Macedonia, there had to be done certain legal changes. The lesson that can be learned is that the laws must be updated based on the changes on a regional and worldwide level. If certain changes need to be done, they need to be done timely. Before the changes in the law, the refugees have illegally crossed the border using the railway. Twenty people were run over by trains.

- The refugee crisis initiates the need for installation of wire fences on certain borders in order to avoid escalation of the situation. Nowadays there are more fences than ever. There are wire fences on the border of Hungary and Serbia, Macedonia and Greece, Bulgaria and Turkey, Greece and Turkey and so on.

- In 2015, according to FRONTEX 1.8 million people entered Europe, and half of them used the East-Mediterranean route. Big number of these people transited through the countries of the Balkan Peninsula. The Balkan countries should be prepared for similar situations in the future.

- Refugees are also a challenge and threat to the national security of any country of transit and stay. The budget for the national security should be increased and the security services to be prepared. The enormous number of refugees in a certain area can be a great challenge and danger.

- The refugee crisis is a great opportunity for transit of the ISIS fighters. The only thing they need to do is to dress in civilian clothes and join in the columns of refugees. Of the total number of ISIS fighters who come from Europe, even $60 \%$ are sent back and await new instructions for further action. The large number of terrorist attacks across Europe is evidence for this. During this refugee crisis, the system for detecting and separating them from the crowd of refugees simply did not exist or did not work appropriately. Returning veterans easily moved across the Balkan route with other identities. I believe that this is the issue that would be the biggest enigma and challenge in time ahead.

- The big difference in the development and widening gap between European countries on the one hand and the African and the Asian continent on the other hand will lead to new migration and refugee crises. Another indicator is that between 5 and 6 billion people live on the area of Africa and Asia, and the resources and living conditions in this part of the world are becoming more severe. In this current refugee crisis there are people from Africa, but the majority comes from Syria, Iraq and Afghanistan. European laws and the liberal way of accepting refugees will only lead to the beginning of new migration processes. 
- The international pressure on countries such as Macedonia with increased number of refugees to close the borders is large. In case of such a situation especially with refugees from Africa, it can be very dangerous for the country that stops the movement, and such a situation will only lead to a profit for the illegal trafficking.

To sum up, although the refugees only transited through the Republic of Macedonia and the Balkan Peninsula, this refugee crisis causes consequences that will be felt in the future. Their goal was not the Balkans, but in the future we must carefully monitor the indicators because there are signs of some movements starting from Africa and even Asia. The great migration can be a very big problem for both, national security and the demographic structure of the population. Based on my analysis, although the Balkan route is closed, we must be vigilant and prepared, not only Macedonia, but the whole region as well. It is calculated that in 2015, on a worldwide level, about 65 million people had to emigrate and leave their homes due to armed conflicts, riots, persecutions etc. If we consider the fact that according to the world average only $1 \%$ of the refugees are returning to their homes, we will understand that the topic that we discuss is very serious.

\section{Bibliography}

Митревска М. (2016), Кризен менаџмент, Скопје: Филозофски факултет. http://www.unrefugees.org/what-is-a-refugee/ http://www.unesco.org/new/en/social-and-human-sciences/themes/ international-migration/glossary/migrant/ http://www.unhcr.org/1951-refugee-convention.html http://morm.gov.mk/wp-content/uploads/2017/01/31_SM0-za-web.pdf http://www.independent.co.uk/ http://library.fes.de/pdf-files/bueros/sofia/12570.pdf http://www.ox.ac.uk/ 